\title{
Training Programmes in Sustainable Forest Management in Austria, Croatia and Slovenia
}

\author{
Silvija Krajter Ostoić ${ }^{1 *}$, Patrick Huber ${ }^{2}$, Marta Curman ${ }^{1}$, Bernhard Wolfslehner ${ }^{2}$, Robert Jandl ${ }^{3}$, Nevenka \\ Bogataj $^{4}$, Todora Rogelja ${ }^{5}$, Andrej Breznikar ${ }^{6}$, Nike Krajnc ${ }^{7}$, Karolina Horvatinčić ${ }^{8}$, Sanja Tišma ${ }^{8}$, Mateja \\ Horvatič ${ }^{4}$, Dijana Vuletić ${ }^{9}$
}

(1) Croatian Forest Research Institute, Division for International Scientific Cooperation in Southeast Europe (EFISEE), Perkovčeva ulica 5, HR-10000 Zagreb, Croatia; (2) The European Forest Institute Central-East and South-East European Regional Office (EFICEEC-EFISEE), c/o University of Natural Resources and Life Sciences, Vienna, Feistmantelstr. 4, A-1180 Vienna, Austria; (3) Austrian Research Centre for Forests (BFW), Seckendorff-Gudent-Weg 8, A-1331 Vienna, Austria; (4) Slovenian Institute for Adult Education, Šmartinska 134a, SI-1000 Ljubljana; (5) University of Padova, Department of Land, Environment, Agriculture and Forestry (TeSAF), Viale dell'Università, 16, I- 35020 Legnaro (PD), Italy; (6) Slovenia Forest Service, Večna pot 2, SI-1000 Ljubljana, Slovenia; (7) Slovenian Forestry Institute, Department for Forest Techniques and Economics, Večna pot 2, SI-1000 Ljubljana, Slovenia; (8) Institute for Development and International Relations, Ljudevita Farkaša Vukotinovića 2, HR-10000 Zagreb, Croatia; (9) Croatian Forest Research Institute, Common Affairs Service, Cvjetno naselje 41, HR-10450 Jastrebarsko, Croatia

* Correspondence: e-mail: silvijak@sumins.hr
Citation: KRAJTER OSTOIĆ S, HUBER P, CURMAN M, WOLFSLEHNER B, JANDL $R$, BOGATAJ N, ROGELJA T, BREZNIKAR A, KRAJNC N, HORVATINČIĆ K, TIŠMA S, HORVATIČ M, VULETIĆ D 2017 Training Programmes in Sustainable Forest Management in Austria, Croatia and Slovenia. South-east Eur for 8 (2): 137146. DOI: https://doi.org/10.15177/ seefor.17-13

Received: 28 Oct 2016; Revised: 20 Sep 2017; 2 Nov 2017: Accepted: 9 Nov 2017; Published online: 24 Nov 2017

\begin{abstract}
Background and Purpose: During the Erasmus+ project "Cooperation for Innovative Approach in Sustainable Forest Management Training (CIA2SFM)" a study of the existing vocational education and training (VET) and lifelong learning (LLL) programmes in the field of sustainable forest management (SFM) was conducted in Austria, Croatia and Slovenia. The aim of this paper is to get an overview of and analyse SFM-related VET and LLL programmes in the study area, with an emphasis on the identification of good practice examples and providing recommendations for improvement.

Materials and Methods: A combined approach of literature review, Internet search and consultations with training providers was applied in order to collect data on training programmes conducted in the period 2006-2015 in Austria, Croatia and Slovenia. The programmes were analysed based on topics, types of methods used, existence of specified learning outcomes, programme evaluation by participants and how the programme was advertised. The analysis employed basic descriptive statistics. Topics were grouped into broader themes. Only training programmes targeting private forest owners, forestry professionals, and forestry entrepreneurs were analysed. Three examples of good practice in each country were selected based on collaboratively developed criteria.

Results: In Austria, Croatia and Slovenia numerous training courses related to SFM were conducted in the analysed period, predominantly addressing target groups in forestry sector and covering a variety of topics. The relative importance of themes varied among countries. In order to facilitate the knowledge uptake by participants various methods were applied. Although indoor ex-cathedra approaches prevailed, it could be recognized that there is a growth in interest for foster demonstrations in the field, organizing field trips, emphasize on practical work and combining methods and approaches in most countries.

Conclusions: Even if national providers of training programmes may relate to individual needs within national forestry sectors, SFM-related training programmes should be regularly screened and updated according to international agendas and emerging issues. In order to cope with increasing uncertainty and expanding risks forest ecosystems are facing, it is an important task to open up the recent training offer to innovative forms of learning, combinations of topics and learning environments.
\end{abstract}

Keywords: vocational education and training, lifelong learning, adult education, knowledge transfer, e-learning, forestry 


\section{INTRODUCTION}

Education has ever since played a crucial role in the development of human communities and society in general. Before the late 18th century and the Age of Enlightenment, access to education had been restricted and limited to privileged individuals [1]. Since then, significant social, economic and political changes have occurred. We are now living in the Knowledge Age that is putting knowledge in focus of socio-economic development and growth [2, 3].

Knowledge can be defined as "the outcome of assimilation of information through learning" [4]. However, there are numerous other definitions $[5,6]$. Modern theoreticians often distinguish among declarative (theoretical), procedural (practical) and conditional knowledge [5]. Declarative (theoretical) knowledge refers to knowing factual information about something; procedural (practical) refers to how to use this knowledge in certain processes or routines, while conditional knowledge refers to understanding when and where this knowledge would be applicable. Knowledge management literature also distinguishes between explicit and tacit knowledge. The former refers to knowledge that the learner is conscious of and easier to transfer, while the latter refers to knowledge that the learner might not be aware of and is largely experience-based [4].

Gaining knowledge implies learning, which is defined as "a process by which an individual assimilates information, ideas and values and thus acquires knowledge, knowhow, skills and/or competence" [4]. According to Cedefop [4], there is a difference among formal, informal and nonformal learning. Formal learning occurs in an organised and structured environment and is intentional, such as learning while taking a part in formal educational system. On the other hand, informal learning is mostly non-intentional and resulting from activities related to work, family or leisure. Finally, non-formal learning is planned and intentional activity, but is not necessarily designed as learning in terms of learning objectives, time and resources.

The quality of human capital is at the heart of the Europe 2020 strategy aiming at smart, sustainable and inclusive growth [7]. Reaching important priorities such as the development a high-employment economy based on knowledge and innovation is not possible without knowledgeable and skilful professionals on the labour market. Hence, Strategic Framework for Education and Training ('ET 2020') puts an emphasis on lifelong learning (LLL) and vocational education and training (VET), and urges them to be more responsive to change and societal needs [8]. VET is defined as education or training that aims to prepare learners for particular occupations, traditionally non-academic and practically oriented, or to equip them to have more advantageous position on the labour market in general $[4,9]$. On the other hand, LLL includes the entire range of learning (formal, informal and non-formal) undertaken throughout life, as well as skills, knowledge, attitudes and behaviours that people acquire in their everyday lives [10].
However, participation of adults in VET and LLL varies across Europe as well as the EU [11]. According to the Education and Training Monitor 2016, adult participation in learning in EU28 is only $10.7 \%^{1}$ on average, whereas target by 2020 is set to $15 \%$. In that sense some Member States are underperforming, for instance Croatia, while others are close to or even beyond the target. In Austria, participation of adults in educational programmes is $14.4 \%$, which is an increase in comparison to 2012 (14.2\%) [12]. On the other hand, in Croatia participation has even dropped (from 3.3\% in 2012 to $3.1 \%$ in 2015) [13]. Even though Croatian Strategy of Education, Science and Technology strongly supports LLL [14], the implementation of the Strategy has been facing serious obstacles due to a lack of political will to tackle the national curricular reform [11]. Furthermore, in 2015 Slovenia was above the EU average in adult participation in learning $(11.9 \%)$, but a drop of almost $2 \%$ has been recorded in comparison to 2012 [11].

EU funds and programmes offer possibilities to access funding for VET and LLL. Erasmust is such a programme that offers opportunities to various types of organisations or individuals regardless of the profession to participate in training programmes often through mobility [15]. The programme's key actions are mobility of individuals, cooperation for innovation and the exchange of good practice, and support for policy reform. ERASMUS+ project 'Cooperation for Innovative Approach in Sustainable Forest Management Training' (CIA2SFM) refers to the second key action and aims at developing collaborative transnational multilingual e-learning modules on sustainable forest management ${ }^{2}$ (SFM) tailored for forestry professionals, forestry entrepreneurs, private forest owners and professionals in public institutions in charge of protected area management [17]. The three-year project involves six public educational and/or research organisations and a forest management company from Austria, Croatia and Slovenia.

Forests and forestry sector are important assets we as a society have on the way towards reaching the European Commission's Bioeconomy Strategy targets [18, 19]. However, forestry sector in Europe is facing many challenges, such as climate change, a shift in forest ownership, as well as increasing and often conflicting societal demands (e.g. timber production, biodiversity, wood-based bioenergy, scenic beauty, protection from natural hazards, provision of drinking water, etc.) [20]. Hence, forestry and other forest-related professionals work in complex and constantly changing (policy) environment urging them to stay on top with their forest-related knowledge, skills and competences [21]. Furthermore, to a various extent there is a mismatch in EU and other European countries between skills obtained through formal educational systems and labour market needs hampering current and future economic competitiveness with forestry sectors not being an exception [22-24]. Consequently, there is a constant need for continuous participation in VET and LLL related to SFM.

After finishing formal education in forestry or adjacent sectors, forestry and other forest related professionals

1 - SFM refers to the stewardship and use of forests and forest lands in a way, and at a rate, that maintains their biodiversity, productivity, regeneration capacity, vitality and their potential to fulfill, now and in the future, relevant ecological, economical and social functions and that does not cause damage to other ecosystems [16]

2 - The share of 25 to 64 year olds who received formal or non-formal education or training in the four weeks preceding the survey. 
and individuals in project countries do not have equal opportunities for constant upgrade of their knowledge, skills and competences related to SFM. For example, in Croatia, two main providers of systematic professional trainings in SFM were established only 10 years ago. Hence, it is not surprising that 30 years ago in Croatia 65\% of the employed forestry professionals never participated in any kind of professional training whatsoever [25]. On the other hand, Austria has a long tradition of providing SFM-related professional training [26]. This affects, among other things, their transition from somewhat protected educational environment to often harsh realities of the labour market. This is especially true in countries with struggling economies, such as Croatia.

Recently a number of studies addressing training programmes have been published in Austria, Croatia and Slovenia. Those were mainly focused on the correlation between VET and the labour market [27-31], the innovative approach in LLL [32,33], VET and LLL policy and state [34-38], the processes of assessment and evaluation of VET [39, 40], and specific methods of LLL [41]. However, those addressing VET and LLL in SFM are scarce [25, 42-46]. Furthermore, none of these analysed the state of the art in SFM-related VET and LLL programmes offered in Austria, Croatia and Slovenia. Hence, the aim of the paper is to present the results of such analysis carried out within the frame of the CIA2SFM project with the purpose of taking stock and providing recommendations for the improvement. The results of this study will be useful for national providers of SFM-related professional training, as well as forestry and education policy actors to improve the existing VET and LLL programmes.

\section{MATERIAL AND METHODS}

Initially, we made a list of VET and LLL providers on topics related to SFM (Table 1). Since we were interested in relatively recent training programmes and because in Croatia main providers of SFM-related training were not established prior to 2006, we agreed on collecting only information on programmes that took place in period 2006-2015. The convenient sampling was applied based on our knowledge, Internet search and direct contact with providers. The following information about each training programme was collected:

- Programme's name, topic and short content: for the purpose of analysis of the programme's topics these were roughly divided into five groups - Forest management and planning, Forest products and services, Safety issues, Forest threats, and Others;

- Year when the programme was conducted, duration and number of training courses: to calculate the average number of provided programmes per year;

- Programme's target group(s): only programmes referring to CIA2SFM project target groups, namely forestry professionals, private forest owners, and entrepreneurs in forestry were analysed in order to see whether and how these groups were addressed by VET and LLL;

- Types of methods used: for the purpose of analysis the methods were roughly divided into four groups - Lectures/presentations, Practical work, Field demonstrations, and Others;

- Specific learning outcomes: in order to see whether they were specified or not;

- Evaluation of the program: in order to see whether the programme was evaluated or not, and if yes, how it was done;

- Programme advertising (promotion): in order to see whether and how the programme's participants were recruited;

- Assessment of the progress of participants: in order to see whether and how the assessment was done.

TABLE 1. A list of major providers of VET and LLL programmes in SFM by country.

\begin{tabular}{|c|c|}
\hline Country & Provider/URL \\
\hline \multirow{4}{*}{ Austria } & National Chamber of Agriculture/ www.lko.at \\
\hline & Austrian Forest Research Centre (BFW)/ www.bfw..ac.at \\
\hline & Forest Training Centres/ www.fastossiach.at; www.fastort.at \\
\hline & University of Natural resources and Life Science (BOKU)/ www.boku.ac.at \\
\hline \multirow{4}{*}{ Croatia } & Croatian Agriculture and Forestry Advisory Service / www.savjetodavna.hr \\
\hline & Croatian Chamber of Forestry and Wood Technology Engineers/ www.hkisdt.hr \\
\hline & European Forest Institute/ www.efi.int \\
\hline & Faculty of Forestry/ www.sumfak.hr \\
\hline \multirow{7}{*}{ Slovenia } & Slovenia Forest Service/ www.zgs.si \\
\hline & Slovenian Forestry Institute/ www.gozdis.si \\
\hline & Secondary Forestry and Wood Processing School in Postojna/ sola.sgls.si/ \\
\hline & University in Ljubljana, Biotechnical Faculty, Department of Forestry and Renewable Forest Resources/ www.bf.uni-lj.si/ \\
\hline & Higher professional school Postojna/ www.vspo.si/ \\
\hline & Union of forestry associations of Slovenia/ zgds.si/ \\
\hline & Slovenian Institute for Adult Education/ www.acs.si \\
\hline
\end{tabular}

NB: Name of the Service in the period 2007-2010 was Forest Extension Service. In the period 2011-2014 it was merged with state forest company Croatian Forests Ltd. From 2014-2017 the name of the Service was Advisory Service. The latest name is Croatian Agriculture and Forestry Service. 
The rationale for taking into account programmes targeting forestry professionals, forestry entrepreneurs and private forest owners is because they were identified during project development phase as those who are lacking continuous (lifelong) training related to SFM. Forestry professionals, especially straight-out-of-faculty forestry engineers, lack specific knowledge and skills to increase their employability on the job market. Experienced forestry engineers who finished faculty long time ago need continuous update, especially due to frequent changes in forest-related polices on the national and EU level. Private forest owners do not necessarily have knowledge and skills needed to perform management activities in their forests since they do not necessarily have formal education in forestry [47]. They are also facing complex administrative and other barriers when trying to engage in management of their forests [48]. In the time of financial austerity, what became essential for these target groups, beside SFM-related knowledge and skills, is having knowledge and skills on how to find additional funding, such as by making a project application.

The available data on the conducted VET and LLL programmes in SFM were collected from official websites of the providers or directly from the providers in case the data were not available online. For that matter, an Excel sheet specifying what information is needed was sent to providers of VET and LLL programmes in SFM, one in Austria, two in Croatia and three in Slovenia, who provided us with the missing information.

Data was collected between November 2015 and January 2016. Due to quite heterogeneous data, a basic descriptive analysis was applied and will be presented in this paper.

After the overview of VET and LLL programmes in SFM was done, the seven criteria (Table 2) were developed collaboratively in the team and used for a selection of examples of good practice. According to the criteria, programmes of higher value were those developed for diverse target groups, offering topics related to the state of the art of SFM, implementing a multi-method approach, as well as those adequately advertised. Less important criteria referred to programme evaluation by its participants and participants' progress assessment. Based on these criteria three examples of good practice per country were selected.

\section{RESULTS}

\section{State of VET and LLL programmes in SFM in Austria, Croatia and Slovenia}

In the given period, several organisations offered a range of VET and LLL programmes in SFM to the target groups in Austria, Croatia and Slovenia. Of particular relevance are four providers in Austria, three in Croatia and seven in Slovenia (Table 1). In Croatia, two major providers, namely Croatian Chamber of Forestry and Wood Technology Engineers, and Forest Extension Service ${ }^{3}$, were established in 2006 as a result of changes in forest policy, which among others aimed at boosting private forest-related entrepreneurship and improving private forests $[49,50]$. Before 2006, there had been no systematical and continuous provision of VET and LLL programmes in SFM. In addition to these major providers, a small number of trainings was provided by the European Forest Institute through a regional project FOPER ("Forest Policy, Economics, Education and Research"), forestry professionals, and the Faculty of Forestry, University of Zagreb, who provided trainings to employees of the Forest Extension Service, state forest company Croatian Forests Ltd., and professionals working on data collection for national forest inventory.

On average around 80 VET and LLL programmes in SFM were conducted every year in Austria in the period from 2006-2015, depending on the interest and resources available because some of them were held only on demand. In Croatia, in the period from 2007-2015, 879 VET and LLL programmes in SFM were held in the period 2007-2015 or on average 98 annually. The Forest Extension Service offered most of them (73\%) targeting private forest owners. However, there was no programme specifically targeting employees of public institutions in charge of the protected areas (nature and national parks), even though in Croatia, forests are the main feature in many of these protected areas. According to Annual reports of Slovenia Forest Service in the period from 2008 to 2015, about 300 VET and LLL programmes in SFM were implemented annually. A relatively high number of offered VET and LLL programmes in SFM could be a result of constantly changing (policy) environment [21] and legislation accordingly, as well as the emergence of challenges, such

TABLE 2. Criteria for the identification of good practice examples of VET and LLL programmes in SFM and their rationale (source: [3]).

\begin{tabular}{ll}
\hline \multicolumn{1}{c}{ Criterion } & \multicolumn{1}{c}{ Rationale } \\
\hline Target groups & A multi-stakeholder approach addressing several target groups at the same time \\
\hline Topics covered & Addressing cutting-edge SFM-related content (e.g. emerging and relevant issues) is preferable \\
\hline Specified learning outcomes & Mandatory (learning outcomes must be specified) \\
\hline Methods applied & $\begin{array}{l}\text { A multi-method approach is preferable, particularly relevant are practical applications } \\
\text { (e.g. training in the field) }\end{array}$ \\
\hline Programme evaluation & Mandatory (although less important) \\
\hline Programme marketing & Multiple marketing channels are preferable \\
\hline Assessment of the progress of participants & Mandatory (although less important) \\
\hline
\end{tabular}

3 - The name of the Service in the period 2007-2010 was Forest Extension Service. In the period 2011-2014 it was merged with state forest company Croatian Forests Ltd. From 2014-2017 the name of the Service was Advisory Service. The latest name is Croatian Agriculture and Forestry Service. 
as climate change impact, new (invasive) pests, or new technology for forest management.

The analysed programmes covered a wide range of topics grouped into several overarching themes (Figure 1) [3]. The majority of programmes in Austria addressed the theme of Forest management and planning (40\%), followed by programmes addressing Forest products and services (25\%), as well as Safety issues (20\%). Other themes were less frequent, such as Forest threats (10\%) or Policies (5\%).

In Croatia the theme of Forest products and services (29\%) was the most relevant, followed by Policies (20\%) and Forest management and planning (19\%). Themes of Forest threats (13\%) and Safety issues (5\%) received less interest. Category Other (14\%) included a variety of topics, such as topics related to project management or VET and LLL in general.

In Slovenia the most relevant themes were Forest management and planning (38\%), as well as Safety issues (36\%). Less relevant were themes of Forest threats (12\%), Forest products and services (7\%), or Education and training in general (3\%).

The analysis of methods used for knowledge transfer showed differences in approaches in project countries (Figure 2) [3]. In Austria there was a good balance of broad portfolio methods applied in order to train different target groups in SFM-related topics. Although ex-cathedra teaching (lectures and presentations) represented a common way to distribute knowledge across classrooms, it can be denoted that object teaching was used often as well. The share of field demonstrations and practical work (altogether 44\%) indicate that hands-on experience was of high relevance. Other methods referred to moderated discussions $(11 \%)$ and tests (4\%) complementing the indoor-based teaching methods. In Croatia there was a clear emphasis on traditional ex-cathedra classroom teaching (Figure 2). Field demonstrations played a minor role in current curricula, while least relevant were practical work and seminars. Quite contrary, practical work in workshop settings dominated as means of knowledge transfer in Slovenia (Figure 2). Seminars and study circles (labelled as 'Other') together with lectures/presentations, as well as field trips complemented the indoor-based teaching methods. Therefore, in overall there was a good mixture of indoor and outdoor teaching approaches applied in SFM training in Slovenia.

The analysis revealed a room for improvement when it comes to the advertising of training programmes. For instance, some were announced only on website and/or by e-mail (for instance when targeting licenced forestry engineers), while other were advertised also in public places (when targeting private forest owners). This might

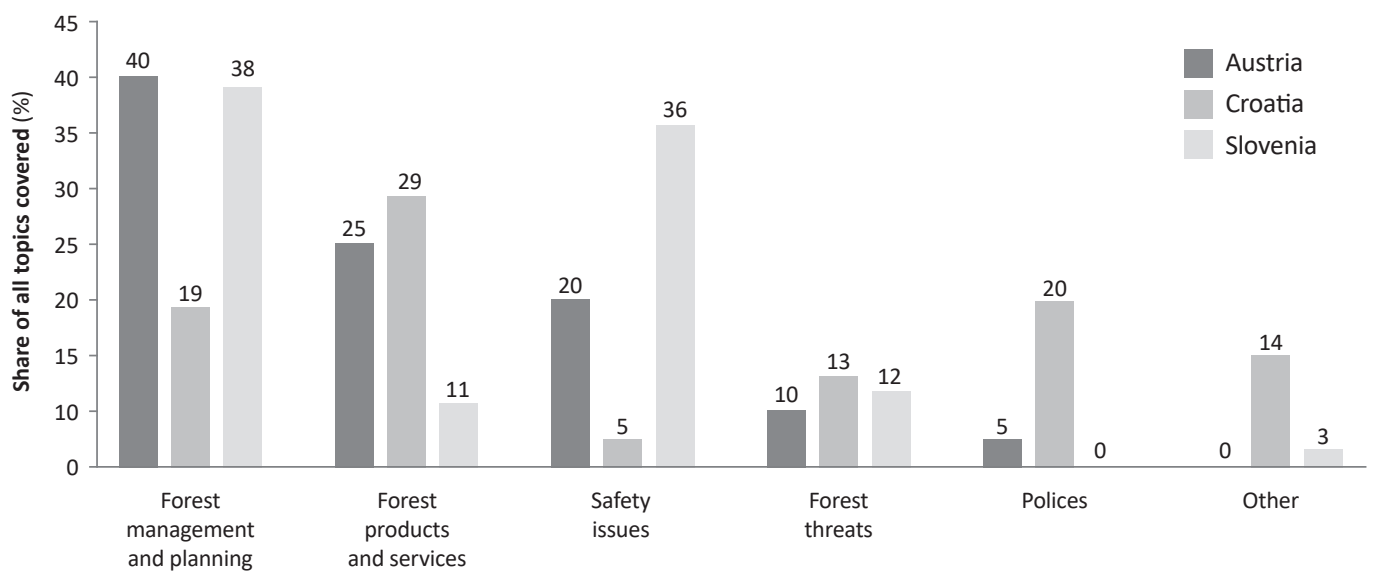

FIGURE 1. Relative share of themes covered in VET and LLL programmes in SFM by country (source: [3]).

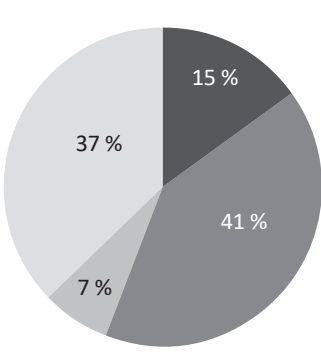

Austria

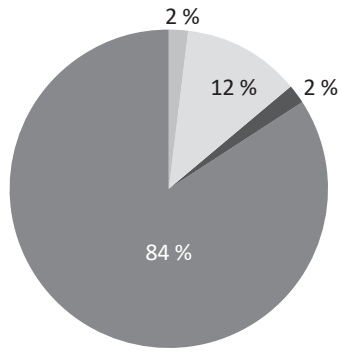

Croatia

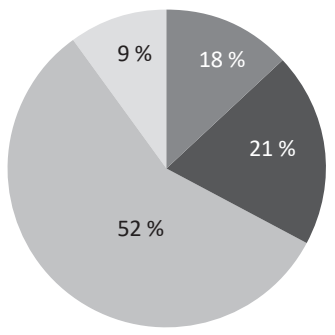

Slovenia
Lecture / presentation

Practical work

Field demonstration

Other

FIGURE 2. Methods applied in SFM-related training programmes by country (source: [3]). 
have affected programme outreach and the number of participants in the end.

When it comes to specifying learning outcomes, the share of programmes with specified learning outcomes varied, while programme evaluation and assessment of participants' progress were less common practices (Table 3).

High share of VET and LLL programmes in SFM in Austria and Slovenia specifically addressed the main competences VET and LLL learners should gain after the completion of individual courses, while in Croatia this has not been a widespread practice. Programme evaluations as well as the assessment of participants' progress have been practiced rarely in all countries (Table 3 ).

\section{Examples of Good Practice in VET and LLL Programmes in SFM}

We identified three examples of good practice in each project country based on a commonly developed set of criteria (Table 4). In Austria these were 'Forest Management Course I', 'Forest Management Course II' and 'The Forest Dialogue' [3]. The first two training programmes were provided by the Austrian Forest Research Center in its Forest Training Centres in Ort and Ossiach. Both training programmes combined lectures with field demonstrations and targeted forest owners and forest workers as well as the general public, hence meeting the multiple target group criterion (Table 4). These programmes were evaluated by participants, learning progress was assessed by exam and participants received certificates of completion. The Forest Dialogue, provided by the Austrian Ministry of Agriculture, Forestry, Water Management and Environment met almost all of the criteria for being qualified as an example of good practice (Table 4). The training programme addressed multiple target groups (forest owners, forestry professionals, forest owner associations, forest scientists, forest administration) and applied the multiple method approach (lectures and presentations complemented by moderated discussions). Apart from being extremely relevant for forest policy in Austria, the programme had specified learning outcomes and was evaluated by participants, but still failed to meet the criteria related to the advertising and assessment of participants' progress.

TABLE 3. Relative shares for selected criteria for the identification of good practice examples of SFM-related training programmes by country (source: [3]).

\begin{tabular}{|c|c|c|c|}
\hline \multirow{2}{*}{ Criterion } & Austria & Croatia & Slovenia \\
\hline & \multicolumn{3}{|c|}{ (\%) } \\
\hline Specified learning outcomes & 87 & 36 & 91 \\
\hline Programme evaluated & 27 & 6 & 34 \\
\hline Participants' progress assessed & 27 & 4 & 9 \\
\hline
\end{tabular}

TABLE 4. SFM-related training programmes deemed as the examples of good practice per country according to the criteria for their selection.

\begin{tabular}{|c|c|c|c|c|c|c|c|c|c|}
\hline \multirow[b]{3}{*}{ Criterion } & \multicolumn{9}{|c|}{ Training programmes deemed as examples of good practice } \\
\hline & \multicolumn{3}{|c|}{ Austria } & \multicolumn{3}{|c|}{ Croatia } & \multicolumn{3}{|c|}{ Slovenia } \\
\hline & $\begin{array}{l}\text { Forest } \\
\text { Mana- } \\
\text { gement } \\
\text { Course I }\end{array}$ & $\begin{array}{l}\text { Forest } \\
\text { Mana- } \\
\text { gement } \\
\text { Course II }\end{array}$ & $\begin{array}{l}\text { Forest } \\
\text { Dialogue }\end{array}$ & $\begin{array}{l}\text { Silvicultural } \\
\text { work/ } \\
\text { biological } \\
\text { regene- } \\
\text { ration }\end{array}$ & $\begin{array}{l}\text { Course } \\
\text { on forest } \\
\text { preser- } \\
\text { vation }\end{array}$ & $\begin{array}{l}\text { Recreational } \\
\text { forest } \\
\text { functions }\end{array}$ & $\begin{array}{l}\text { Forest } \\
\text { manage-ment } \\
\text { and silvicultu- } \\
\text { ral measures } \\
\text { after natural } \\
\text { disasters }\end{array}$ & $\begin{array}{l}\text { PAWS MED } \\
\text { training } \\
\text { course } \\
\text { for forest } \\
\text { pedagogy }\end{array}$ & $\begin{array}{l}\text { Course for } \\
\text { Study Circle } \\
\text { leader and } \\
\text { mentors }\end{array}$ \\
\hline Multiple methods & + & + & + & + & + & + & + & + & + \\
\hline $\begin{array}{l}\text { Multiple target } \\
\text { groups }\end{array}$ & + & + & + & - & - & - & + & + & + \\
\hline Topic relevance & + & + & + & + & + & + & + & + & + \\
\hline $\begin{array}{l}\text { Programme } \\
\text { evaluation }\end{array}$ & + & - & + & - & + & - & + & + & + \\
\hline $\begin{array}{l}\text { Multiple } \\
\text { advertising } \\
\text { channels }\end{array}$ & - & - & - & + & + & + & + & + & + \\
\hline $\begin{array}{l}\text { Participants' } \\
\text { progress } \\
\text { assessment }\end{array}$ & + & - & - & + & + & + & - & + & + \\
\hline
\end{tabular}

Legend: (+) criterion met; (-) criterion not met 
In Croatia, the Forest Advisory Service provided all selected examples of good practice (Table 4). Those referred to training programmes on 'Silvicultural work on biological regeneration', 'Course on forest preservation' and 'Recreational forest functions' [3]. In all these training programmes learning outcomes were specified, multiple methods were applied (lectures accompanied with demonstrations, exercise and practical examples) and assessment of participants' progress was conducted. Through a short questionnaire the participants evaluated only the 'Course on forest preservation'. The course 'Recreational forest functions' addressed an increasingly relevant topic due to increasing societal demands toward forests, especially in urban areas.

Several providers implemented Slovenian examples of good practice. The course 'Forest management and silvicultural measures after natural disasters' was provided by the Biotechnical Faculty, University of Ljubljana, Slovenian Forestry Institute and Slovenia Forest Service. The second example of good practice, the 'PAWS MED training course for forest pedagogy', was provided by the Slovenia Forest Service and the PAWS MED project group, while 'The basic training for Study Circle leader and mentors', was provided by the Slovenian Institute for Adult Education [3]. Each Slovenian example of good practice addressed various target groups, such as forestry professionals, forestry students and teachers, hunters, nature conservationists, civil society, forest owners, researchers, etc. Furthermore, in all examples, multiple methods were applied (beside indoor and outdoor presentations, methods included practical work, group work and discussion), learning outcomes were specified, programme evaluation by participants conducted, and various means for promotion of the training programmes used.

\section{DISCUSSION AND CONCLUSIONS}

Lessons Learnt and Suggestions for the Improvement of SFM-Related VET and LLL Curricula in Austria, Croatia and Slovenia

Although the existence of various SFM-related professional training programmes in the study area is evident, still there is room for improvement. In all countries, there is a need for (i) upgrading educational approaches through specification of learning outcomes, programme evaluation, assessment of participants' progress and increase of advertising efforts, (ii) clustering potential participants according to their knowledge level, and (iii) integrating innovative means of knowledge transfer.

Specified learning outcomes should be stated in each VET and LLL programme in SFM in order to give clear indication of the main skills and competences the trainees are supposed to obtain during a course. This is of special importance for Croatia (Table 3). The analysis showed that programme evaluation and the assessment of participants' progress were weak spots in all countries. While programme evaluation is pertinent for receiving feedback from participants on the respective training, programme assessment is important for assessing the level of gained knowledge and trainees' readiness for further career [39]. However, both may be taken up for the further development and/or improvement of the courses [3, 39, 40,51]. In order to secure the successful knowledge transfer, the assessment of participants' progress should be further developed and conducted through various tools, such as an exam, a portfolio, a short essay, practical work or a certification [3, 39, 51].

The importance of dissemination of respective information material to potential learners in order to attract them to participate in VET and LLL programmes in SFM is indisputable today. Although the utilization of multiple channels exists, the suggestion is to use social media as well, which is becoming more popular nowadays and is offering a diverse set of tools for communication beneficial to foster the broad distribution towards specific target audiences [3].

Further advancement may be achieved by clustering potential participants according to their knowledge level. Since forestry and forest-related sectors include various stakeholders (from private forest owners over nature conservationists to forestry professionals) who can become lifelong learners in SFM, a pyramid of needs may well represent their learning demands (Figure 3 ). It represents the level of knowledge that might be appropriate for a certain group of learners and highlights an approach to cluster individuals according to the level of knowledge they may need to obtain in order to gain a certain level of expertise. The pyramid is divided into three categories and indicates the entry point at which trainee accesses SFM-related VET and LLL. Basic denotes the lowest level of knowledge provided and offers learners a starting point in SFM. L1 provides professional knowledge and skills on a broad portfolio of topics related to SFM, and L2 ensures gaining expert level know-how in a certain domain of SFM [3].

The use of innovative methods for knowledge transfer such as study circles and e-learning in the existing or new curricula is highly recommended in all countries in the study area. Study circles represent non-individual learning approaches with an emphasis on dialogue and aim at linking educational or training messages with local needs and specifics and to empower by engagement in selfselected topics, usually representing the strengths of the target group [52]. This includes i) setting learning goals in a small group, ii) self-selected location, intensity and structure, and iii) obligatory final public presentation of

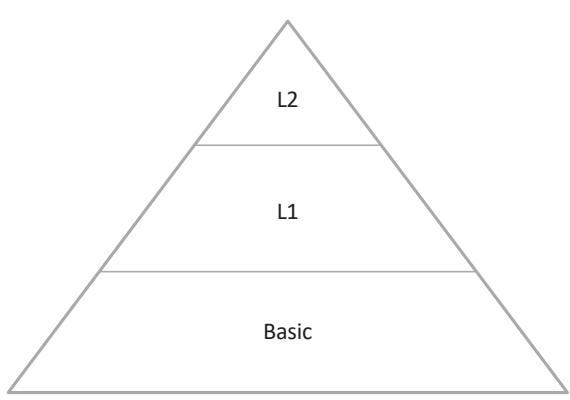

FIGURE 3. Generic scheme for clustering adult learners based on the level of knowledge (source: [3]). 
learning results and gains [3]. Study circles directly address local needs, engage local people and materialize results [52], thus they are useful for complex issues such as SFM [3] and for learners with basic level of knowledge. E-learning refers to distance education and training supported by information and communication technologies [4]. Some of the major advantages of e-learning adoption are: improving access to education, improving student choice over when, where and how to engage in the learning processes, improving efficiency and effectiveness of education, saving time and money since there is no need for the trainees or teachers to travel and possibility to upgrade the learning material up-to-date [53, 54]. However, main disadvantages are related to the physical separation between the teacher and the trainee, especially when there is a problem which may be difficult to solve or a problem in comprehending course information [53]. With regard to our target groups, e-learning courses are more suitable for younger forestry professionals, and employees of public institutions related to nature protection. They often work in remote areas and have main preconditions for e-learning, which are computer literacy and Internet access. On the other hand, study circles are applicable for all target groups regardless of age, but could be especially useful for older participants that are often not tech savvy.

Even if programmes' topics may relate to national needs within forestry sectors, they should be regularly screened and updated according to international agendas and emerging issues [3]. In order to cope with increasing uncertainty and expanding risks forest ecosystems are facing, it is an important task to open up recent training offer to innovative forms of learning, combinations of topics and learning environments.

\section{Limitations of the Study}

The analysis took into account training programmes that we were able to obtain either from Internet search on providers' websites or directly from major providers. We did not take into account trainings that may be related to SFM but were not specifically targeting our target groups. For instance, in Croatia training on how to operate safely with chain saw is provided by several other providers. However, these providers are targeting general population. Provided data did not allow exploration of programmes' outreach in terms of the number of participants in each programme. We are aware that the final list of programmes provided to our target groups is not comprehensive, and probably some programmes have been left out due to sampling procedure. However, we think that we succeeded in mapping the majority of training programmes and the most important providers in these countries, allowing us to identify examples of good practice, as well as weak points, and provide recommendations for the improvement.

We believe this paper is valuable in its attempt to provide suggestions and recommendations on how to improve VET and LLL programmes related to SFM in the analysed countries. Hence, it would be primarily relevant for training providers in analysed countries, but also for other organisations promoting VET and LLL or those working on the development of education policies.

\section{Acknowledgments}

The paper was developed as a result of the ERASMUS+ project 'Cooperation for Innovative Approach in Sustainable Forest Management Training (CIA2SFM)' (2015-1-HR01-KA202-013064) coordinated by the Croatian Forest Research Institute. We would like to thank all providers of training programmes in Austria, Croatia and Slovenia (Table 1) for their cooperation during data collection and analysis. Responsibility for views presented in the paper lies completely with authors and not with the European Commission, ERASMUS+ programme or the Croatian Agency for Mobility and EU Programmes.

\section{REFERENCES}

1. IVIĆ V 2009 Pučko narodno i građansko školstvo u slobodnom i kraljevskom gradu Osijeku u 18. i 19. stoljeću. Anali Zavoda za znanstveni i umjetnički rad u Osijeku, sv. 25: 103 - 130. URL: https://hrcak.srce.hr/file/75988 (28 June 2016)

2. TAN SC, HUNG D, SCARDAMALIA M 2006 Education in the Knowledge Age- Engaging learners through knowledge building. In: Hung D, Khine MS (eds) Engaged Learning with Emerging Technologies. Springer, Netherlands, pp 91-106. DOI: https://doi.org/10.1007/1-4020-3669-8 5

3. HUBER P, WOLFSLEHNER B 2016 The Study on Good Practice in VET and LLL in SFM in Austria, Croatia and Slovenia. Project Deliverable. ERASMUS +. URL: http://www.cia2sfm. org/wp-content/uploads/2016/06/THE-STUDY-ON-GOODPRACTICE-IN-VET-AND-LLL-IN-SFM v2 final.pdf (28 June 2016)

4. CEDEFOP 2008 Terminology of European education and training policy. A selection of 100 key terms. European Centre for the Development of Vocation Training. Luxembourg: Office for Official Publication of the European Communities. URL: www.cedefop.europa.eu/files/4064 en.pdf (28 June 2016)
5. ALEXANDER PA, SCHALLERT DL, HARE VC 1991 Coming to Terms: How Researchers in Learning and Literacy Talk about Knowledge. Rev Educ Res 61 (3): 315-343. URL: http://www. jstor.org/stable/1170635?seq=1\#page scan tab contents (28 June 2016)

6. DE JONG T, FERGUSON-HESSLER MGM 1996 Types and Qualities of knowledge. Educ Psychol 31 (2): 105-113. DOI: https://doi.org/10.1207/s15326985ep3102 2

7. EUROPEAN COMMISSION 2010 A New Impetus for European Cooperation in Vocational Education and Training to Support the Europe 2020 Strategy. URL: http://eur-lex.europa.eu/ legal-content/EN/TXT/PDF/?uri=CELEX:52010DC0296\&from =EN (17 June 2016)

8. THE COUNCIL OF EUROPEAN UNION 2009 Council conclusion on 12 May 2009 on a strategic framework for European cooperation in education and training ('ET 2020'). Official Journal of the European Union C 119/2, Bruxelles, Belgium. URL: http://eur-lex.europa.eu/legal-content/EN/TXT/PDF/?u ri=CELEX:52009XG0528(01)\&from=EN (17 June 2016) 
9. EUROPEAN AGENCY FOR SPECIAL NEEDS AND INCLUSIVE EDUCATION 2013 Vocational Education and Training: Policy and practice in the field of special needs education (VET). URL: https://www.european-agency.org/agency-projects/ vocational-education-and-training (28 June 2016)

10. LAAL M, SALAMATI P 2011 Lifelong learning; why do we need it? Procd Soc Behv 31: 399-403. DOI: https://doi. org/10.1016/j.sbspro.2011.12.073

11. EUROPEAN COMMISSION 2016a Education and Training Monitor 2016. URL: https://ec.europa.eu/education/sites/ education/files/monitor2016 en.pdf (17 June 2016)

12. EUROPEAN COMMISSION 2016b Education and Training Monitor 2016. Austria. URL: https://ec.europa.eu/education/ sites/education/files/monitor2016-at en.pdf (17 June 2016)

13. EUROPEAN COMMISSION 2016c Education and Training Monitor 2016. Croatia. URL: https://ec.europa.eu/ education/sites/education/files/monitor2016-hr en.pdf (17 June 2016)

14. CROATIAN PARLIAMENT 2014 Strategy of Education, Science and Technology. Official Gazette 124/2014, Zagreb, Croatia. URL: http://narodne-novine.nn.hr/clanci/ sluzbeni/2014 10124 2364.html (17 June 2016)

15. EUROPEAN COMMISSION 2016d Erasmus+ Programme Guide. Version 2, 07/01/2016. URL: https://ec.europa.eu/ programmes/erasmus-plus/sites/erasmusplus/files/files/ resources/2016-erasmus-plus-programme-guide-v-ii en.pdf (17 June 2016)

16. THE MINISTERIAL CONFERENCE ON THE PROTECTION OF FORESTS IN EUROPE 1993 RESOLUTION H1 General Guidelines for the Sustainable Management of Forests in Europe. URL: http://www.foresteurope.org/docs/MC/MC helsinki resolutionH1.pdf (17 June 2016)

17. CIA2SFM 2017 About. URL: http://www.cia2sfm.org/ (17 June 2016)

18. EUROPEAN COMMISSION 2012 Innovating for Sustainable Growth. A Bioeconomy for Europe. Directore General for Research and Innovation. URL: http://bookshop.europa.eu/ en/innovating-for-sustainable-growth-pbKI3212262/ (17 June 2016)

19. OLLIKAINEN M 2014 Forestry in bioeconomy - smarth green growth for the human kind. Scand J Forest Res 29 (4): 360366. DOI: https://doi.org/10.1080/02827581.2014.926392

20. EUROPEAN COMMISSION 2013 Communication from the Commission to the European Parliament, the Council, the European economic and social committee, and the Committee of regions. A new EU Forest Strategy: for forests

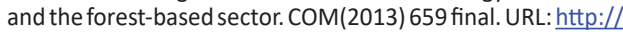
eur-lex.europa.eu/resource.html?uri=cellar:21b27c38-21fb11e3-8d1c-01aa75ed71a1.0022.01/DOC 1\&format=PDF (17 June 2016)

21. WILLIAMSON TB, ISAAC KJ 2012 Adapting sustainable forest management to climate change: an overview of approaches for assessing human adaptive capacity. Can. Counc. For. Minist., Ottawa, Canada. URL: http://www.ccfm.org/pdf/ ENG AdaptiveCapacity Prf8.pdf (17 June 2016)

22. INTERNATIONAL LABOUR ORGANIZATION 2014 Skills mismatch in Europe - Statistics Brief. URL: http://www. ilo.org/wcmsp5/groups/public/---dgreports/---stat/ documents/publication/wcms 315623.pdf (17 June 2016)

23. BARTLETT W 2013 Skill Mismatch, Education Systems, and Labour Markets in EU Neighborhood Policy Countries. URL: $\quad$ http://www.ub.edu/searchproject/wp-content/ uploads/2013/09/WP05.20.pdf (17 June 2016)

24. BEJAKOVIĆ P, MRNJAVAC Ž 2013 Skill mismatches and anticipation of the future labour market need: case of Croatia. The Tenth International Conference: "Challenges of Europe: The Quest for New Competitiveness". URL: https:// bib.irb.hr/datoteka/675599.bejaovic-mrnjavac.pdf (17 June 2016)
25. ŠAJKOVIĆ A 1986 Stručno usavršavanje i inventivni rad visokostručnog kadra u šumarstvu SR Hrvatske. Sumar list 110 (5-6): 19-27

26. BFW 2017 "Baum fällt" - 60 Jahre Forstliche Ausbildungsstätte Ossiach. URL: https://bfw.ac.at/db/bfwcms.web?dok=9784 (17 June 2016)

27. PERIN V 2013 Vocational education and the labour market: the Concept of flexicurity. Život $i$ škola LIX (30): 147-154

28. TAFRA V 2013 Learning and training for entrepreneurship and educational system - strategic approach. Učenje za poduzetništvo 3 (1): 16-21

29. RELJA R, BEŠKER M 2011 Vocational education in function of employment in the labor market of Split. Andragoški glasnik: Glasilo Hrvatskog andragoškog društva 15 (2)

30. BOHUŠ M, PAVELIĆ I 2011 The development of entrepreneurial competence in vocational education - good practice example. Učenje za poduzetništvo 1 (1): 381-390

31. VOGTENHUBER S 2014 The impact of within country heterogeneity in vocational specificity on initial job matches and job status. J Voc Behav 84 (3): 374-384. DOI: https://doi. org/10.1016/i.jvb.2014.08.012

32. MARTINKO J 2012 Workshop- the method of interactive learning and teaching of the adults. Andragoški glasnik: Glasilo Hrvatskog andragoškog društva 16 (2): 165-174

33. BALAŽı S, VRBAN S 2011 Novi mediji u cjeloživotnom obrazovanju. Andragoški glasnik: Glasilo Hrvatskog andragoškog društva 15 (2)

34. BAKETA N 2012 Europeanisation of adult education in Croatia. Andragoški glasnik: Glasilo Hrvatskog andragoškog društva 16 (1): 55-67

35. LUGARIĆ M 2012 On the importance of adult education. Andragoški glasnik: Glasilo Hrvatskog andragoškog društva 16 (2): 95-98

36. PAVLOVIĆ BOLF O 2012 Changes in EU programmes for adult education Andragoški glasnik : Glasilo Hrvatskog andragoškog društva 16 (2): 175-180

37. BRANDSTETTER G, FINGERLOS A, LUOMI-MESSERER K, PROKOPP M 2009 National VET Research Report Austria. Vienna, Austria. URL: http://www.equi.at/dateien/NRR Austria EN.pdf (17 June 2016)

38. LASSNIGG L 2016 "Muddling Through" Once Again - The Long Term Development of the Dualistic Austrian VET System. In: Berner E, Gonon P (eds) History of Vocational Education and Training in Europe. Cases, Concepts and Challenges. Studies in vocational and continuing education (14), Peter Lang. Bern, Switzerland, pp 125-145

39. RAJIĆ V 2013 Evaluation of educational outcomes in adult education. Andragoški glasnik: Glasilo Hrvatskog andragoškog društva 17 (2): 117-124

40. PETRIČEVIĆ D 2012 Examination, Assessment and Validation of Qualifications Gained through Non-Formal and Informal Learning. Andragoški glasnik: Glasilo Hrvatskog andragoškog društva 16 (2): 99-116

41. BOGATAJ N, DEL GOBBO G, SLANISCA E 2012 Study circle for local development: lifelong oriented models and operators competences in the cross border area Italy- Slovenia. In: Formazione e Insegnamento European Journal of research on Education and Teaching anno X, nu. 2. pp 255-268

42. ČODERL J, JAMNIK Z, BOGATAJ N 2012. Povezovanje lastnikov gozdov in učenje za skupno gospodarjenje - izkušnje KE Radlje. In: Marenče J (ed) Povezovanje lastnikov gozdov in skupno gospodarjenje: zbornik razširjenih izvlečkov. 1. izd. Ljubljana: Biotehniška fakulteta, Oddelek za gozdarstvo in obnovljive gozdne vire. pp 54-55. URL: http://web.bf.uni-lj. si/go/gsd2012/povzetki/14\%C4\%8Coderl.pdf (17 June 2016) 
43. KOTNIK A, WINKLER I 2005 Izobraževalne potrebe in gozdarsko znanje lastnikov gozdov na gozdnogospodarskem območju Novo mesto = Educational needs, knowledge and skills of forest owners in the forest management region of Novo mesto. In: Adamič M, Winkler I (eds) Prihodnost gospodarjenja z zasebnimi gozdovi $\mathrm{v}$ Sloveniji = Future of private forest management in Slovenia, (Strokovna in znanstvena dela, ISSN 0353-6025, št. 123). Ljubljana: Biotechnical Faculty, Department of Forestry and Renewable Forest Resources. pp 253-268

44. BOGATAJ N 2005 Participative learning as a forestry extension tool in the Alpine rural environment: a case study of the Solčava area. In: Robek R, Arzberger U (eds) Forest operation improvements in farm forestry in Slovenia : workshop proceedings : Logarska Dolina, Slovenia, 9-14 September 2003. Rome: UNFAO. pp 263-275

45. MEDVED M 2002 Educating private forest owners at a crossroads. Gozdarski vestnik 60 (3): pp 129-152

46. LANDEKIĆ M, MARTINIĆ I, BAKARIĆ M, RICART MR, ŠPORČIĆ M 2017 Stručno osposobljavanje radnika u sektoru šumarstva - stanje u Hrvatskoj i trendovi u Europi. Sumar list 141 (7-8): 395-407

47. GLÜCK P, AVDIBEGOVIĆ $M$, ČABARAVDIĆ $A$, NONIĆ $D$, PETROVIĆ N, POSAVEC S, STOJANOVSKA M, IMOČANIN S, KRAJTER S et al. 2011 Private forest owners in the Western Balkans - ready for the formation of interest associations. European Forest Institute, Joensuu, Finland, Research Report 25. URL: http://www.efi.int/files/attachments/publications/ efi rr 25 2011.pdf (17 June 2016)
48. KRAJTER OSTOIĆ S, POSAVEC S, PALADINIĆ E, ŽUPANIĆ M, BELJAN K, CURMAN M, ĆALETA M, N. ŠIMUNOVIĆ N 2015 Forest land ownership change in Croatia. In: Živojinović I, Weiss G, Lidestav G, Feliciano D, Hujala T, Dobšinska Z, Lawrence A, Nybakk A, Quiroga S, Schraml U (eds) COST Action FP1201 FACESMAP Country Report. Vienna: European Forest Institute Central-East and South-East European Regional Office, pp. 101-27

49. CROATIAN PARLIAMENT 2003 National Forest Policy and Strategy. Official Gazette 120/2003, Zagreb, Croatia. URL: http://narodne-novine.nn.hr/clanci/ sluzbeni/2003 $07 \quad 120 \quad$ 1663.html (17 June 2016)

50. CARVALHO MENDES AMS, ŠTEFANEK B, FELICIANO D, MIZARAITE D, NONIĆ D, KITCHOUKOV E, NYBAKK E, DUDUMAN G, WEISS G, NICHIFOREL L, STOYANOVA M, MÄKINEN P, ALVES R, MILIJIĆ V, SARVAŠOVÁ Z 2011 Institutional Innovation in European Private Forestry: The Emergence of Forest Owners' Organizations. Chapter $B$ in: Innovation in Forestry: Territorial and Value Chain Relationships. CABI Publishing, pp 68-86

51. MARTINIĆ I, LANDEKIĆ M, ŠPORČIĆ M, LOVRIĆ M 2011 Croatian Forestry at the Doorstep of EU - How Much are We Ready in the Area of Occupational Safety in Forestry? Croat J For Eng 32 (1): 431-441

52. BOGATAJ N 2010 Female forest owners: contribution to the complex understanding of old people in Slovenia. Kakovostna starost 13 (1): 38-49

53. HANNAY M, NEWVINE T 2006 Perceptions of distance learning: a comparison of online and traditional learning. Journal of Online Learning and Teaching 1 (2): 1-11

54. ARKORFUL V, ABAIDOO N 2015 The role of e-learning, advantages and disadvantages of its adoption in higher education. International Journal of Instructional Technology and Distance Learning 1 (12): 29-42 